\title{
Time out
}

\section{HENRIK BJELKE}

Det var en sovsekande med parallelle sider, så, den lignede et rektangel, men den var buet i enderne som en båd, en fladbundet båd med en cirkelrund forsænkning i midten. Oven i den stod en flaske, som passede lige så fint ned i bunden af sovsekanden. Flasken havde en hvid prop, og jeg tænkte: Hvem har stillet den der? Det er ikke noget, der tilhører huset. Har der været nogen herinde, jeg ikke har hørt, mens jeg sov inde i soveværelset bag en lukket dør (af hensyn til en bestemt fjendtligt indstillet flue, som hjemsøgte mig i morges eller en af de andre gange, jeg sov, hvor det var, ligesom om det var morgen)? Men jeg kunne ikke huske at have hørt lyde af nogen, og det forbavsede mig egentlig, at der stod en genstand i køkkenet, som jeg ikke havde stillet der, og som jeg vidste ikke tilhørte utensilierne i det her hus indtil jeg opdagede, at jeg ikke var kommet op men havde drømt, at jeg var stået op. På denne måde blev forskellen mellem at ligge og sove og ikke ligge og sove men være stået op til dels udslettet. Ingen forskel mellem bevidst og ubevidst, og derfor findes ingen bevidsthed, eller også er man forsvindingspunktet $\mathrm{i}$ en eneste stor bevidsthed. Da jeg opdagede, at jeg måtte have drømt sovsekanden med flasken, disse fremmede genstande som jeg havde truffet kan man ikke sige, som jeg havde observeret, efter at jeg var stået op - nej, jeg kan ikke. -Jeg lå og sov og troede, at jeg var stået op, og da jeg opdagede, at jeg ikke var stået op, stod jeg op. Og der stod ikke nogen sovsekande med nogen flaske ude i køkkenet, der stod ikke nogen fremmede ting der.

Når vejret ikke er sommerligt, kan det ikke nytte at bilde sig ind, at man ved at sidde ude har det lige så varmt, som man har det ved at sidde inde. Og selv om det skulle ligne sommerligt 
vejr, ved at lyset er der, og nogle skyer går væk, så solen skinner, er det en illusion, for der er lige så koldt, som hvis solen ikke havde skinnet, og det havde været gråvejr.

Jeg prøver at sidde uden for huset, når jeg ikke kan holde ud at sidde indenfor, men jeg bliver altid nødt til at gå ind igen. $\mathrm{Og}$ når jeg har siddet et stykke tid indenfor, bliver jeg hele tiden nødt til at sætte mig udenfor igen. Så jeg sidder henholdsvis indenfor og udenfor, uden at der egentlig er nogen særlig stor forskel, men jeg trækker vejret bedre udenfor, kan jeg mærke, eller også er det de elektriske varmeapparater indenfor, som giver mig hovedpine. Nu har jeg slukket for dem og har tændt op i kaminen for at få noget varme, der måske ikke giver mig hovedpine. Så behovet for at flytte ud for at komme af med hovedpinen forsvinder måske fuldstændigt, så jeg kan sidde inde hele tiden - og have det, som om jeg sad udenfor.

Jeg mærkede dog en forskel mellem dag og nat, eller også var det en forskel mellem at være på landet og være i byen, ved at jeg, i aftes, da jeg ankom, kunne mærke en meget stærk lugt af, kan det have været af hyldetræerne? - det tror jeg ikke, jeg gik i dag hen, hvor jeg kunne se et hyldetræ, og lugtede til det, men det lugtede ikke godt. Men det lugtede godt, da jeg kom i aftes i, ikke nattens mulm og mørke, men i en meget neddæmpet lysstyrke, da duftede det meget tydeligt. Af planter må det have været, eller af græsset, eller af træerne. En meget tydelig fornemmelse af ikke at være $\mathrm{i}$ byen, en anden lugt end lugten i byen. Men i dag, da jeg kunne se de træer og de planter og det græs, der må have lugtet i nat, kunne jeg ikke spore nogen lugt, som var anderledes, jeg kunne lugte noget, nej, jeg kunne ikke lugte noget, for jeg kunne ikke lugte noget trafik, jeg kunne ikke lugte noget benzin. Men jeg kunne heller ikke lugte de planter, jeg kunne lugte i nat. Der er noget af det man kalder nat, og noget andet man kalder dag. Men det er ikke strengt nødvendigt for mig at opretholde denne sondring, der trods kalenderens præpositioner, sol „op" $\mathrm{kl}$. 4.28, sol „ned“ kl. 21.55, næsten ikke gælder i det ydre - bortset fra at det bliver lidt mørkere om natten, men det bliver ikke helt mørkt, og det bliver lidt lysere om dagen, men det bliver ikke helt lyst, det er gråvejr, og der er lovet gråvejr de næste fem dage, såkaldte 
dage, så den herskende situation er jævnt tåget, et jævnt gråligt billede, som står fuldstændig ubevægeligt dag og nat, der er tilmed lovet vindstille, og det står stille, fuldstændigt, al ting står fuldstændig stille. Ingenting i det ydre forlanger noget af mig, ingen rytme andet end sulten og tørsten og afføringen og søvnen, og disse behov tilfredsstiller jeg i den rækkefølge, hvori de melder sig. Og det kan man så kalde en rytme, men den er sekundær i forhold til de rytmer, jeg kommer fra, som hedder at gå på arbejde, at komme hjem fra arbejde og så videre. Der er heller ingen medmennesker at skulle indpasse sig efter, eller som skal indpasse sig efter en. Der er ingenting.

Jeg slipper i nogle dage og nogle nætter for at spille nogen rolle, for der er ikke nogen at spille nogen rolle for. Og når der ikke er det, så er der heller ikke nogen rolle at spille, så det spiller ingen rolle, jég spiller ingen rolle. Jeg har papirer og optegnelser med, som jeg skulle se på, og jeg har bøger med, som jeg skulle læse. Men tilskyndelsen til at gøre nogen af delene mangler. Jeg læser i en bog, der hedder Amerika, skrevet af en franskmand, der har været en tur i Amerika, men jeg læser langsomt, og jeg er egentlig lige glad, om jeg får det læst eller ej. Den enkelte sætning virker spændende i det øjeblikjeg læser den, og bagefter kan jeg ikke huske noget. Men jeg kan kende fornemmelsen af Amerika med disse evige motorveje og de store tomme ørkener og de store vidder og de ensomme mennesker, det endeløst vulgære, og den giver også et bud på fremtiden. Det er, som om fremtiden allerede er her. Vi ved ikke, hvad der kommer, men det gør vi heller ikke med hensyn til det, der er her. Der er nogle ting og nogle genstande og nogle træer og noget vand og nogle marker, men det er mere eller mindre tomt for betydning. Det her hus er tomt bortset fra mig, men jeg spiller ikke nogen rolle, så jeg er også tom med hensyn til det, der plejer at være mig, nemlig de roller jeg spiller, så man kan ikke af nogen grund sige, at jég er hér. Man hviler sig her. Der er ikke fjernsyn, det vil sige, at der heller ikke er klokken halvotte-nyhederne, som danner i hvert fald ét punkt på dagen, som man kan forudsige. Der er en radio, men jeg ved ikke, hvordan man bærer sig ad med at bruge den, bortset fra at jeg godt kan finde ud af at tænde for den, men jeg 
har ingen programmer, jeg har ingen oversigt over, hvad det er de sender nu, eller hvad det er de sender nu på nogle andre kanaler, som ligger ved siden af den kanal, jeg tilfældigvis stiller ind på; og det, de tilfældigvis vælger at bringe, er jeg uinteresseret $i$, og hvis jeg havde kunnet se et program og kunnet fatte interesse for noget i radioen, havde jeg kunnet lukke op og høre det, men da jeg ikke har nøglen til, hvad den vil sende, kan jeg ikke påstå, at jeg har forstand på at bruge radioen, så den kan ikke siges at strukturere noget af det stykke tid, jeg tilbringer her. Jeg har forskellige kassettebånd med, men jeg kender indholdet af de fleste af dem og kan ikke beslutte mig for, hvad for et af dem, jeg vil høre, så derfor lader jeg være med at høre nogen af dem.

Jeg har tændt op i kaminen, som buldrer i flammer. Jeg har smækket begge kamindørene i og lukket spjældene, så det kan brænde noget længere, men alligevel falder der et stykke brændende træ ud af kaminen. Jeg skal ikke kunne sige, om det er ligesom sovsekanden med flasken i, som viste sig at være en "drøm", eller om det her er en virkelighed, som ikke kan have foregået, men som jeg alligevel lagde mærke til. Jeg var nødt til at tage en klud omkring håndtaget på kaminen og lukke kamindøren op og skovle det lille stykke brændende træ tilbage i kaminen. Jeg gad nok vide, hvordan det er kommet ud af to lukkede kamindøre af jern, men det kan også være, jeg er noget, en anden har drømt.

Ved udsigten til at skulle tilbringe noget, der ellers ville have repræsenteret fem dage og fem nætter her alene i et hus, hvor det er gråvejr, kunne man frygte, at jeg skulle blive overmandet af en angst for den tomhed, som dette ustrukturerede ophold vil være ensbetydende med. Men jeg er ikke overmandet af nogen angst ved at befinde mig i en tomhed, som jeg nu rent kronologisk kan konstatere allerede har varet i tyve timer, hvis det skal tælles op i timer. Det er ikke noget billede på den virkelighed, jeg oplever, at jeg kalder det tyve timer. Jeg kalder det et stykke væren her mere eller mindre bevidst, mere eller mindre bevidstløs, mere eller mindre træt og mere eller mindre oplagt. Jeg er på den anden side heller ikke særlig optimistisk med hensyn til udfoldelse af energi i en fire-fem dage. Jeg er i det hele taget ikke op- 
fyldt af nogen særlige følelser med hensyn til, hvad der skal foregå. Jeg kunne tænke mig at sidde og kigge ud over vandet. Jeg kan gennem vinduet se vandet fra stuen. Hvad der generer mig er, at hver gang jeg har besluttet mig for at rejse mig op og gå hen og lukke døren op og kigge direkte ud på vandet i stedet for at kigge på det gennem ruden, kommer der altid lige ud for, hvor jeg står, en bil kørende eller en person gående nede på vejen, der ligger mellem mig og vandet. Der er en mærkelig form for idiotisk magnetisme i, at der, hver gang man vil ud og kigge på det, er nogle andre, der kommer i vejen. Men det er lykkedes mig at komme ud nogle gange, hvor der ikke var nogen, og gå ned over marken til vandet og stå foran det. Og gå lidt frem og tilbage langs vandet. Men da jeg så skal op igen, er der som regel en bil eller en gammel kone eller, hvad skal vi sige, noget levende, som, med et udtryk, man ikke kan bruge om dyrene, "kommer i vejen", og så må jeg blive lidt længere nede på stranden for ikke at rende ind i vedkommende person eller personbil, som jeg ikke kan finde ud af at have en måde at forholde mig til. Det er en irritation. Det irriterer mig, at tingene skal kollidere. Min irritation bliver vakt ved overhovedet at registrere noget andet menneske end mig, og mig er jeg fri for at registrere. Delvis. For jeg føler ikke, at jeg er til stede, medmindre en anden person bliver opfattet af det i mig, der opfatter noget som helst. Er der i en tidsperiode, hvis længde jeg har svært ved at opfatte, og som jeg derfor har svært ved at udmåle, ingen registrering af noget andet menneske (dyr gør mig ikke noget, dem registrerer jeg ikke, dem indarbejder jeg ligesom en del af landskabet), er der heller ingen registrering af noget som helst at foretage for mig, eller det af mig, der registrerer. Det registrerer ikke, det tænker ikke, det er ikke, og så passer pengene. Man kunne jo lige så godt forestille sig, at jeg var gået ud af huset og ned til stranden og op igen og var kommet inden for dørene, og at bilen så var kommet kørende forbi, eller at den var kommet kørende forbi, før jeg havde åbnet døren og var gået ud. Men det er som om beslutningen bliver taget, samtidig med at bilen er på vej herhen, sådan at når den bringes til udførelse, ér bilen på det her sted, og det vil sige, at det er et spørgsmål om bad timing. Men hvordan skulle man bære sig 
ad med at time sin beslutning i forhold til et ukendt antal biler eller personer, som kan finde på også ifølge bad timing at komme kørende? Deres årsager ligger tidligere. Hvis det er en bil, ligger der måske en beslutning om dẹt på et kvarter-tyve minutter eller adskillige timer, eller jeg ved ikke hvad, forud for, at den befinder sig ud for mit synsfelt, og det samme gælder en person, så det må, da der er en kortere afstand mellem huset og stranden, end der er mellem det her sted mellem huset og stranden og så de respektive steder, som de respektive biler eller personer kommer fra, være mine beslutninger, der skal times bedre, da de kan tages senere end de andres. Mine årsager til disse uvelkomne møder ligger senere end de andres årsager eller medårsager til disse kedelige følger og burde få mig til at sørge for ikke at løbe ind i allerede trufne beslutninger og deres uundgåelige følger. Men hvordan skulle jeg bære mig ad med at undgå møder, når jeg blot ønsker at følge mine impulser ureflekterende, u-existerende, præcis som landskabet selv, som jeg føler mig ud i et med, lige så gråt, tåget og udflydende det er? Ikke ved at holde op med at tænke, for det er jeg allerede holdt op med, men ved ikke at begynde på det igen ved synet af nogen, hvem jeg tillægger den egenskab, at de tænker. Det vil sige, ved at udnævne eventuelt forekommende personer i landskabet til at være en del af det. Men det forhindrer deres måde at være til stede i landskabet på mig i. Havde der gået en fredelig bonde og pløjet, en hyrde og passet får, en kone og samlet brænde eller sten, havde det været lidt mindre besværligt at anskue fænomenet som del af landskabets indhold. Men det anakronistiske landskab er fattigt på tilsvarende anakronismer. Landskabet er for umoderne for den slags personer, som jeg hele tiden nødsages til at opfatte og døje. Det er for øvrigt morsomt at lægge mærke til, at de mennesker, man ser, næsten alle sammen er barhovedede og enten gråhårede og kortklippede, mænd og kvinder ser ligedan ud, eller skaldede, og næsten alle sammen iført noget tøj i hvide eller lysegule eller lyseblå eller lysegrå farver, som om de er iført et bestemt lystøj, og de virker på mig som turister, der skuffede går rundt i et regnfuldt og diset og tåget landskab og spejder efter et øjeblik, hvor den solskinssituation, som de har forestillet sig, og som er 
deres motivation for at komme her, skal indfinde sig, og de udviser en vis træthed og kedsomhed ved ventetiden på, at det skal blive dette idylliske sommervejr. Men jeg kan overhovedet ikke identificere mig med dem, fordi jeg er ikke her for at søge et bestemt øjeblik, som jeg har med mig, jeg er ikke engang sikker på, jeg ved, hvorfor jeg er her. Jeg er ikke engang sikker på, om jeg er her. Eller også er jeg mere eller mindre identisk med landskabet, mere eller mindre sammenflydende med landskabet, men uden dets tolerance, så deres tilstedeværelse virker på mig, som om de er turister, de virker som lus og lopper, der kravler hen over min ryg, og som jeg helst vil ryste af. Min eneste trøst er, at der sikkert er forholdsvis få af dem, sammenlignet med hvor mange der ville være, hvis vejret havde været anderledes. Jeg kan lige nu ikke forestille mig noget mere bedrøveligt end sommerklædte, halvgamle turister, der trætte og kedsommelige spadserer forbi på den her strand og kigger på det her vand uden rigtigt at opfatte, hvad de ser.

Farven på himlen er mere eller mindre den samme, som hvis det ikke havde regnet, grålig, ja, grå, der er egentlig ingen nuancer i det, den er lysegrå. Det lader til at holde naboerne væk, det såkaldt dårlige vejr, jeg har ikke observeret beboere i hverken huset til venstre eller huset til højre for dette her hus i form af lyde af mennesker eller køretøjer, og det vil sige, at det grå vejr overlader mig til disse evige ting, himlen og havet og de forkrøblede bjergfyr og regnen og luften. Når jeg siger evige, så er det i forhold til min evighed, som begynder, da jeg bliver født, og ender, når jeg dør. Jeg er i virkeligheden født her, selv om jeg ikke er født her, for det var her, det begyndte.

Det regner en gang imellem og holder igen op med at regne. Da jeg trak gardinerne fra i morges, så jeg, at der var hvidt skum på bølgerne, og at havet fra at have været gråligt var mere blåt, eller rettere mere mørkeblåt i det, og himlen havde også forskellige andre farver. Når jeg siger farven grå, så kunne jeg lige så godt sige, at den ingen farver havde, at den var farveløs; men den havde nogle andre farver af farven grå end grå. Det stormede og så meget forskelligt ud fra da det ikke stormede. Det faldt mig ind, at lige meget hvordan vejret er, virker synet af havet som en 
trøst, en opmuntring på grund af sit konstante udseende. Det har nøjagtig samme udseende, som det havde for mange, mange år siden, for 50 år siden og for 1000 år siden for den sags skyld, men det ér det samme vand, som jeg altid husker, og derfor bringer dette at kunne vågne op fra søvnen og se dette samme hav efter at have været $i$ en helt anden verden (som altid mer eller mindre udspiller sig ved denne havbugt) mig en følelse af konstans i tilværelsen.

Der er intet som helst at se på, der er en tomhed og en ensformighed, som jeg altid har kendt, og som jeg altid har følt mig som en del af. Inden for det utal af nuanceforskelle i selv det mest unuancerede gråvejr, som dette grålige landskab ligger hen i, er der næppe en nuance, som jeg ikke genkender. Uden måske at se direkte på det som barn har jeg alligevel på et eller andet tidspunkt set alle former for vejrlig, lysstyrke og stadier i vegationens op- og afblomstringer, for hvordan skulle jeg ellers kunne genkende det, jeg nu ser, eller for den sags skyld alt, hvad jeg nogen sinde ser her? Og jeg genkender hele tiden det, jeg hele tiden ser, selv om jeg eller nogen anden end mig, for dens sags skyld, jo ikke kan siges at have været i det næste nu før nu. De samme buske og de samme træer og det samme løv og den samme marehalm, det samme græs og det samme vand og den samme himmel og det samme landskab, det er et fuldstændig konstant billede, som har eksisteret her og inde i mit hoved hele mit liv. Og uanset hvilke andre strande jeg har gæstet, har jeg altid tænkt, det er det samme vand som her, det er bare ikke helt så godt, eller det er ikke helt ligesådan, men det ligner. Og det har manglet altid, når jeg har været væk fra det, går det op for mig, så det jeg sidder overfor, som er et intet, en udsigt til noget gråvejr og noget vand og noget himmel, dette intet er i virkeligheden alt, fordi det er det, som alt det andet altid har manglet, selv når alt det andet har bestået af noget, der også var en strand, et andet sted.

Klokken er nu halvfire ifølge mindst to ure, og jeg tror, det er søndag. Det vil sige, at jeg nu har været her siden torsdag aften, hvor jeg har skiftevis sovet og været vågen, været indenfor og været udenfor og en enkelt gang kørt ud og købt ind, men stort 
set bevæget mig i meget små mønstre. Kommer nogen forbi, gemmer jeg mig ligesom dyrene, der ikke vil ses, som harerne eller rævene, det gælder om ikke at blive set, men i modsætning til dyrene i en konstant bestræbelse på at holde landskabet fri af præsens, fordi det ikke skal farves ind af nogen tilstedeværelse, der vedrører lige nu, i dette år, i denne uge, på denne dag, i denne time. Det har nogle dimensioner af en anden art, og disse dimensioner får det tilbage, så snart et fremmedlegeme er forsvundet fra mit synsfelt, det være sig en bil eller en person. Og jeg vil ikke ses af nogen af den grund, at jeg så med det samme automatisk forestiller mig, at de betragter den person, de ser, som en der også er her på samme måde, som de er her. Men det er ikke sådan, jeg er her, og derfor så vil jeg ikke ses af nogen. Jeg venter - selv om jeg har klædt mig på for at gå ud, men må tøve, fordi der står nogen på stranden - til de er gået væk, og så går jeg ud. Det er muligt, at jeg i svage øjeblikke ønsker at befolke det, jeg ser nu, som er tomt, med minder fra fortiden. Men det er ikke bestemte dage i fortiden eller bestemte timer, det er samtlige dage og samtlige timer, jeg på en eller anden måde genkalder mig ved synet af det tomme landskab. Og hvis jeg en gang imellem kommer i tanker om en episode eller nogle mennesker, som for længst boede her eller som jeg for længst havde noget at gøre med, så er det toppe af isbjerge, hvor hele resten slet ikke ses, og hvor disse toppe i og for sig ikke repræsenterer specifikke tidspunkter, men er repræsentanter for det kvantum muligheder for erindring, som det tomme landskab tilbyder. Det slår mig med forbløffelse, at jeg fra at sidde ved bordet inde i huset og tænke eller ikke tænke blot ved at rejse mig og lukke en dør op kan se direkte ud på noget vand, der ser præcis ud, som det også så ud alle de gange jeg, uden at ane det, i min fortid så på det vand. Jeg er samtlige øjeblikke i fortiden, i det øjeblik jeg ser det vand, fordi det vand ser ud, som det gjorde i fortiden, og som jeg øjensynlig kan huske, at det gjorde, bare ved at se på det. Så jeg er uden for tiden eller også er jeg al den tid, jeg har haft, samlet i ét øjeblik af tid. Synet af havet fratager mig min alder. Synet af havet gør alle de begivenheder, der er indtruffet i løbet af mit liv, ubetydelige. Reducerer dem til krusninger på overfladen. Det kan godt få mig 
til at glemme dem, men det kan også få mig til at huske dem, men det får mig til ikke at opholde mig ved dem. De tårer, der er fældet, i øjeblikke af latter eller smerte, og de forståelser eller misforståelser og de glæder eller bekymringer, som har været gældende, og som er holdt op med at være gældende, bliver ikke sprunget over, men frataget deres alder ved at stå konfronteret med dette endeløst ligeglade, men hvis jeg vil det, evigt trofaste vidne, havet, som har været den eneste genkendelige konstante ydre og indre faktor i løbet af det stykke levetid, man foreløbig har haft, hvis brugen af perfektum-formen overhoved har noget korrelat $\mathrm{i}$ virkelighedens verden. 